\title{
Persistence of humoral and cellular immune response after SARS-CoV-2 infection: opportunities and challenges
}

\author{
Tangchun $\mathrm{Wu}(\bowtie)$ \\ School of Public Health, Tongji Medical College, Huazhong University of Science and Technology, Wuhan 430030, China \\ (C) Higher Education Press 2020
}

The emerging COVID-19 pandemic caused by SARS$\mathrm{CoV}-2$ infection has created a global crisis. Under the circumference of no effective treatment or vaccine, the Chinese government has implemented multifaceted measures of social distancing, home isolation, and centralized quarantine, which achieved a remarkable result of controlling the COVID-19 outbreak [1]. However, the personal, psychological, economic, and societal consequences of the shutdown and physical distancing make it difficult to sustain these public health interventions for a long time [2]. To find a new balance between curbing the pandemic and minimizing the indirect effects on society, a better understanding of adaptive immunity in response to SARS-CoV-2 infection is required. Monitoring B cell and $\mathrm{T}$ cell immunological memory activated by SARS-CoV-2 over a prolonged period is essential in anticipating durable protection after infection and in developing vaccines. If maintained at sufficiently high levels, the immune response could effectively block re-infection, which might confer long-lived protection $[3,4]$. Even though, the case report of re-infection with completely different SARS-CoV-2 strains from the first episode [5] raised widespread public concern for the "immune passport" and virus mutation. Despite the urgent need to answer these crucial scientific questions, limited studies have systemically evaluated the long-term humoral and cellular immunity.

Therefore, the study by Tan et al. [6] has great importance in filling the knowledge gap (Table 1 provides summaries of studies on the dynamics of antibody response after SARS-CoV-2 infection). The study reported that the IgG antibody of 17 COVID-19 patients were detectable at 6-7 months after diagnosis, although the concentrations were slightly lower compared to results in

Received October 5, 2020; accepted October 5, 2020

Correspondence: Tangchun Wu,wut@mails.tjmu.edu.cn the early 2 weeks to 2 months. This is the longest observation of antibody dynamics to our best of knowledge so far. Another novel observation from this study was that 14 samples showed durable neutralizing activities in a pseudovirus assay, with no difference in blocking the cellentry of the 614D and $614 \mathrm{G}$ variants of SARS-CoV-2 [6]. Moreover, the study [6] provided compelling evidence that both interferon $\gamma$-producing $\mathrm{CD} 4^{+}$and $\mathrm{CD} 8^{+} \mathrm{T}$ cells were increased in response to SARS-CoV-2 antigen stimulation as compared with non-stimulated samples at 6-7 months post-infection. Taken together, this study has provided the most updated evidence for the persistence of humoral and cellular immunity over a relatively longer period, and susceptibility to second infection for mutant coronavirus among convalescent patients. As the level of neutralizing antibodies against the SARS-CoV-2 spike protein (to block viral entry) is the key to evaluate the protection against reinfection, these findings would inform therapeutic strategies and guide public health intervention.

The study by Tan et al. [6] has its limitation of small sample size and not using the plasma samples from the same patients in different periods. A recent serological study in Iceland [7] evaluated the longitudinal changes in antibody levels among 487 recovered patients with two or more serum samples and found that the antiviral antibodies against SARS-CoV-2 did not decline within 4 months after diagnosis by RNA test [7]. On the contrary, some reports [8-10] observed decay in IgG or neutralizing antibodies among the recovered patients during 2-3 months postinfection, particularly among the asymptomatic participants $[9,10]$. The potential interpretations for the disparity may include the inherent difference of humoral immune responses for asymptomatic and symptomatic infections [11] (time course and duration), and the relatively short observation period of antibody dynamics (typically less than 4 months) in prior investigations [8]. The majority of 


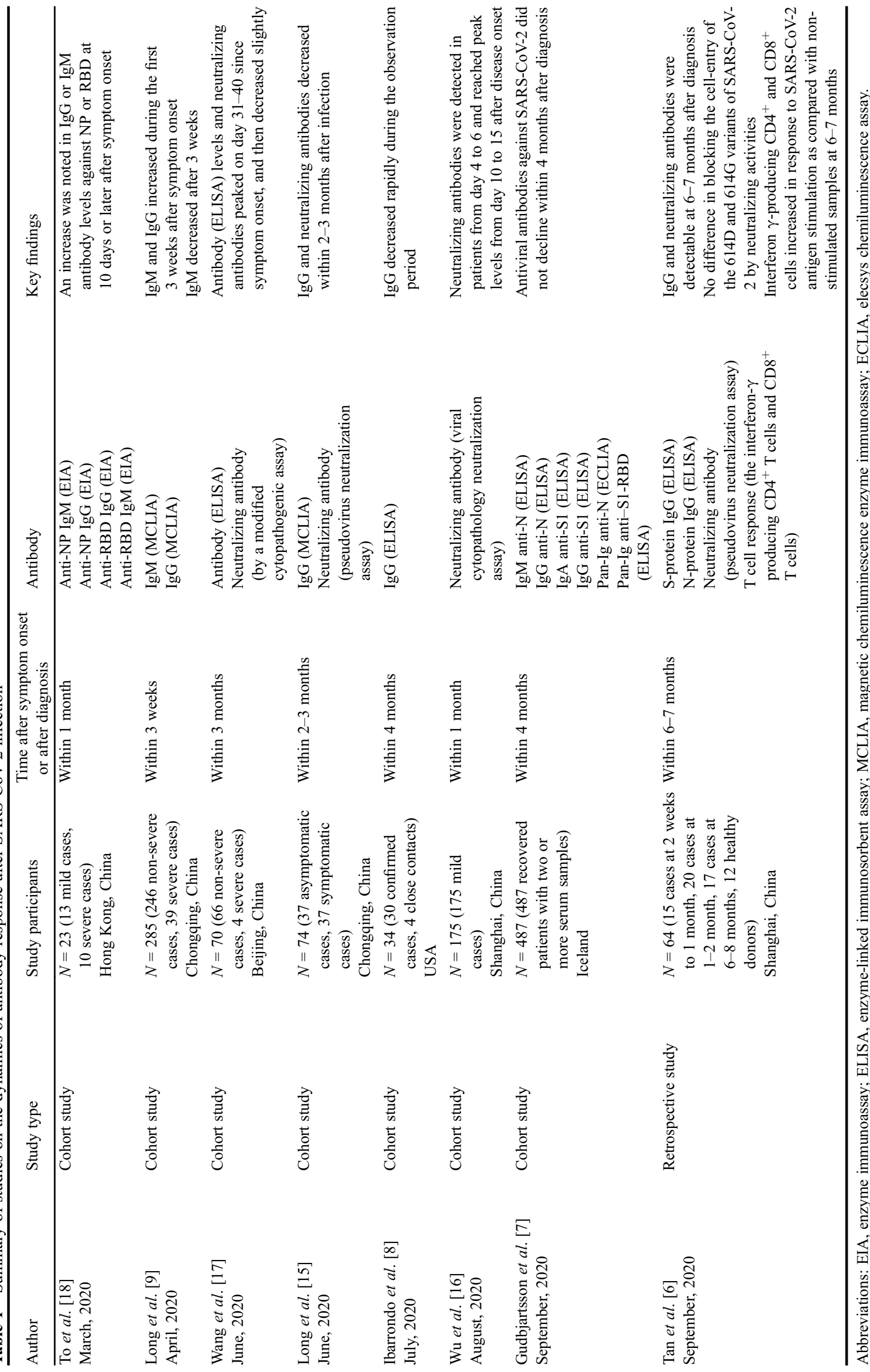


the plasmablasts (B cells) are short-lived, which may contribute to the decay of antibody levels after the acute phase of infection [4]. Meanwhile, the effector $\mathrm{CD} 8^{+} \mathrm{T}$ cell response exhibited a similar pattern as the B cell $[3,4]$. After the early decay phase, serological memory is maintained by a smaller number of longer-lived plasma cells that provide sustained immunity in the absence of antigen $[3,4]$. Therefore, samples collected during the early recovery phases may reflect a transient waning process [3]. By contrast, observations over a prolonged period would lead to more accurate modeling of the immune response [3]. The findings would ease the public apprehension regarding the decline of neutralizing antibody levels and the possibility of subsequent infection. However, it remains largely unclear how long the antibodies will persist at the needed protection threshold, and more studies are still needed.

The outbreak of COVID-19 in China during early 2020 was mainly caused by the 614D SARS-CoV-2 variant. However, the emerging 614G SARS-CoV-2 variant occurs more frequently among the recently infected individuals, which was reported to be more infectious than the original 614D variant in vitro and animal studies [12]. In Tan et al.'s study, although most convalescent patients were infected by the $614 \mathrm{D}$ variant, the neutralizing activities in blocking the cell-entry of the $614 \mathrm{D}$ and $614 \mathrm{G}$ variants at 6 months post-infection showed no significant differences [6]. The results indicated that vaccines developed for the $614 \mathrm{D}$ variant might also confer protection for the $614 \mathrm{G}$ variant. B cells and $\mathrm{T}$ cells both play an important role in the immune protection against SARS-CoV-2. The antibodies are generated by B cells, which would recognize and bind to the coronavirus and prevent cell entry. On the other hand, T cells mainly function as a target for killing the infected cells $[13,14]$. Most existing literature regarding immune protection against SARS-CoV-2 discussed the sustainability of antibody response [7,15-18], whereas less evidence were available for T cells durability $[14,19]$. Tan et al.'s study highlighted that interferon $\gamma$-producing $\mathrm{T}$ cells $\left(\mathrm{CD}^{+}\right.$and $\mathrm{CD} 8^{+}$cells) were increased in response to SARS-CoV-2 antigen stimulation as compared to nonstimulated samples during 6-7 months post-infection [6]. The finding has important implications for ongoing vaccine development.

Elucidating the persistence of humoral and cellular immunity would provide us a powerful tool for modeling individual immune protection and developing vaccine distribution plans. However, many of the critical variables of the immune response (e.g., neutralizing potency for mutant coronavirus and minimally needed protection threshold) still remain largely unknown. Although the whole world is now waiting for the results from phase 3 vaccine trials, the study by Tan et al. [6] has its unique contribution to help understand the durability of the antibody levels from nature infection. More studies with larger samples size and repeated measures are urgently needed to validate the findings.

\section{Compliance with ethics guidelines}

Tangchun $\mathrm{Wu}$ declares that he has no conflict of interest. This manuscript does not involve a research protocol requiring approval by the relevant institutional review board or ethics committee.

\section{References}

1. Pan A, Liu L, Wang C, Guo H, Hao X, Wang Q, Huang J, He N, Yu $\mathrm{H}$, Lin $\mathrm{X}$, Wei S, Wu T. Association of public health interventions with the epidemiology of the COVID-19 outbreak in Wuhan, China. JAMA 2020; 323(19): 1915-1923

2. Mulligan MJ. An inactivated virus candidate vaccine to prevent COVID-19. JAMA 2020 Aug 13. [Epub ahead of print] doi: 10.1001/jama.2020.15539

3. Alter G, Seder R. The power of antibody-based surveillance. N Engl J Med 2020 Sep 1. [Epub ahead of print] doi: 10.1056/ NEJMe2028079

4. Stephens DS, McElrath MJ. COVID-19 and the path to immunity. JAMA 2020 Sep 11. [Epub ahead of print] doi: 10.1001/ jama.2020.16656

5. To KK, Hung IF, Ip JD, Chu AW, Chan WM, Tam AR, Fong CH, Yuan S, Tsoi HW, Ng AC, Lee LL, Wan P,Tso E, To WK, Tsang D, Chan KH, Huang JD, Kok KH, Cheng VC, Yuen KY. COVID-19 re-infection by a phylogenetically distinct SARS-coronavirus-2 strain confirmed by whole genome sequencing. Clin Infect Dis 2020 Aug 25. [Epub ahead of print] doi: 10.1093/cid/ciaa1275

6. Tan Y, Liu F, Xu X, Ling Y, Huang WJ, Zhu ZQ, Guo MQ, Lin YX, Fu ZY, Liang DG, Zhang TF, Fan J, Xu M, Lu HZ, Chen SJ. Durability of neutralizing antibodies and T-cell response post SARS-CoV-2 infection. Front Med 2020; 14(6): 746-751

7. Gudbjartsson DF, Norddahl GL, Melsted P, Gunnarsdottir K, Holm $\mathrm{H}$, Eythorsson E, Arnthorsson AO, Helgason D, Bjarnadottir K, Ingvarsson RF, Thorsteinsdottir B, Kristjansdottir S, Birgisdottir K, Kristinsdottir AM, Sigurdsson MI, Arnadottir GA, Ivarsdottir EV, Andresdottir M, Jonsson F, Agustsdottir AB, Berglund J, Eiriksdottir B, Fridriksdottir R, Gardarsdottir EE, Gottfredsson M, Gretarsdottir OS, Gudmundsdottir S, Gudmundsson KR, Gunnarsdottir TR, Gylfason A, Helgason A, Jensson BO, Jonasdottir A, Jonsson H, Kristjansson T, Kristinsson KG, Magnusdottir DN, Magnusson OT, Olafsdottir LB, Rognvaldsson S,le Roux L, SigmundsdottirG, Sigurdsson A, Sveinbjornsson G, Sveinsdottir KE, Sveinsdottir M,Thorarensen EA, Thorbjornsson B, Thordardottir M, Saemundsdottir J, Kristjansson SH, Josefsdottir KS, Masson G, Georgsson G, Kristjansson M, Moller A, Palsson R, Gudnason T, Thorsteinsdottir U, Jonsdottir I, Sulem P, Stefansson K. Humoral immune response to SARS-CoV-2 in Iceland. N Engl J Med 2020 Sep 1. [Epub ahead of print] doi: 10.1056/ NEJMoa2026116

8. Ibarrondo FJ, Fulcher JA, Goodman-Meza D, Elliott J, Hofmann C, Hausner MA, Ferbas KG, Tobin NH, Aldrovandi GM, Yang OO. Rapid decay of anti-SARS-CoV-2 antibodies in persons with mild Covid-19. N Engl J Med 2020; 383(11): 1085-1087 
9. Long QX, Liu BZ, Deng HJ, Wu GC, Deng K, Chen YK, Liao P, Qiu JF, Lin Y, Cai XF, Wang DQ, Hu Y, Ren JH, Tang N, Xu YY, Yu LH, Mo Z, Gong F, Zhang XL, Tian WG, Hu L, Zhang XX, Xiang JL, Du HX, Liu HW, Lang CH, Luo XH, Wu SB, Cui XP, Zhou Z, Zhu MM, Wang J, Xue CJ, Li XF, Wang L, Li ZJ, Wang K, Niu CC, Yang QJ, Tang XJ, Zhang Y, Liu XM, Li JJ, Zhang DC, Zhang F, Liu P, Yuan J, Li Q, Hu JL, Chen J, Huang AL. Antibody responses to SARS-CoV-2 in patients with COVID-19. Nat Med 2020; 26(6): 845-848

10. Lei Q, Li Y, Hou HY, Wang F, Fan XL. Antibody dynamics to SARS-CoV-2 in asymptomatic and mild COVID-19 patients. medRxiv 2020. Preprint posted July 9

11. Wu J, Liang BY, Chen CR, Wang H, Zheng X. SARS-CoV-2 infection induces sustained humoral immune responses in convalescent patients following symptomatic COVID-19. medRxiv 2020. Preprint posted July 21

12. Korber B, Fischer WM, Gnanakaran S, Yoon H, Theiler J, Abfalterer W, Hengartner N, Giorgi EE, Bhattacharya T, Foley B, Hastie KM, Parker MD, Partridge DG, Evans CM, Freeman TM, de Silva TI, Sheffield COVID-19 Genomics Group; McDanal C, Perez LG, Tang H, Moon-Walker A, Whelan SP, LaBranche CC, Saphire EO, Montefiori DC, Angyal A, Brown RL, Carrilero L, Green LR, Groves DC, Johnson KJ, Keeley AJ, Lindsey BB, Parsons PJ, Raza M, Rowland-Jones S, Smith N, Tucker RM, Wang D, Wyles MD. Tracking changes in SARS-CoV-2 spike: evidence that D614G increases infectivity of the COVID-19 virus. Cell 2020; 182(4): 812-827.e19

13. Leslie M. T cells found in coronavirus patients 'bode well' for longterm immunity. Science 2020; 368(6493): 809-810

14. Sekine T, Perez-Potti A, Rivera-Ballesteros O, Strålin K, Gorin JB, Olsson A, Llewellyn-Lacey S, Kamal H, Bogdanovic G, Muschiol S, Wullimann DJ, Kammann T, Emgård J, Parrot T, Folkesson E; Karolinska COVID-19 Study Group, Rooyackers O, Eriksson LI,
Henter JI, Sönnerborg A, Allander T, Albert J, Nielsen M, Klingström J, Gredmark-Russ S, Björkström NK, Sandberg JK, Price DA, Ljunggren HG, Aleman S, Buggert M. Robust T cell immunity in convalescent individuals with asymptomatic or mild COVID-19. Cell 2020; 183(1):158-168.e14

15. Long QX, Tang XJ, Shi QL, Li Q, Deng HJ, Yuan J, Hu JL, Xu W, Zhang Y, Lv FJ, Su K, Zhang F, Gong J, Wu B, Liu XM, Li JJ, Qiu $\mathrm{JF}$, Chen J, Huang AL. Clinical and immunological assessment of asymptomatic SARS-CoV-2 infections. Nat Med 2020; 26(8): 1200-1204

16. Wu F, Liu M, Wang A, Lu L, Wang Q, Gu C, Chen J, Wu Y, Xia S, Ling Y, Zhang Y, Xun J,Zhang R, Xie Y, Jiang S, Zhu T, Lu H, Wen $\mathrm{Y}$, Huang J. Evaluating the association of clinical characteristics with neutralizing antibody levels in patients who have recovered from mild COVID-19 in Shanghai, China. JAMA Intern Med 2020 Aug 18. [Epub ahead of print] doi: 10.1001/jamainternmed.2020.4616

17. Wang X, Guo X, Xin Q, Pan Y, Hu Y, Li J, Chu Y, Feng Y, Wang Q. Neutralizing antibodies responses to SARS-CoV-2 in COVID-19 inpatients and convalescent patients. Clin Infect Dis 2020 Jun 4. [Epub ahead of print] doi: 10.1093/cid/ciaa721

18. To KK, Tsang OT, Leung WS, Tam AR, Wu TC, Lung DC, Yip CC, Cai JP, Chan JM, Chik TS, Lau DP, Choi CY, Chen LL, Chan WM, Chan KH, Ip JD, Ng AC, Poon RW, Luo CT, Cheng VC, Chan JF, Hung IF, Chen Z, Chen H, Yuen KY. Temporal profiles of viral load in posterior oropharyngeal saliva samples and serum antibody responses during infection by SARS-CoV-2: an observational cohort study. Lancet Infect Dis 2020; 20(5): 565-574

19. Le Bert N, Tan AT, Kunasegaran K, Tham CYL, Hafezi M, Chia A, Chng MHY, Lin M, Tan N, Linster M, Chia WN, Chen MI, Wang LF, Ooi EE, Kalimuddin S, Tambyah PA, Low JG, Tan YJ, Bertoletti A. SARS-CoV-2-specific T cell immunity in cases of COVID-19 and SARS, and uninfected controls. Nature 2020; 584 (7821): 457-462 